\title{
Impact of Corporate Reputation Dimensions on Consumer Trust
}

\author{
Jurgita Stravinskiene, Migle Matuleviciene, Rimante Hopeniene
}

\author{
Kaunas University of Technology \\ K.Donelaicio str. 73, LT-44239, Kaunas, Lithuania \\ E-mail.jurgita.stravinskiene@ktu.lt; migle.matuleviciene@gmail.com; rimante.hopeniene@ktu.lt
}

cross $^{\text {ref }}$ http://dx.doi.org/10.5755/j01.ee.32.2.27548

\begin{abstract}
As global and local crises continue to destabilize stakeholders' trust in organizations, they need to find a long-term solution to the problem of declining trust. A critical marketing task for the sustainability of any business is to focus on the organization's reputation as a valuable, sustainable, and intangible asset of the organization. Growing trust in business is associated with corporate reputation that highlights company's values and beliefs, shows the ways the company is trying to achieve its goals, to fulfil consumers' expectations and its commitments. In some cases, a company does not even have to try to earn stakeholder trust as this function is performed by corporate reputation that develops positive stakeholders' attitude towards the company as a reliable subject in the relationship. An analysis of the organization's reputation and stakeholder trust in the organization revealed a lack of a systematic approach to how the reputation of one organization affects the trust of customers. The research focuses on the issue of consumer trust, consumer being one of the most important stakeholders. Differences in the impact of corporate reputation dimensions on consumer trust are noticed in different sectors, which creates the need for in-depth study of the issue. The aim of the article is to estimate the impact of corporate reputation on consumer trust and to determine which dimensions of corporate reputation affect different types of consumer trust. Empirical research findings are based on the case of pharmacy network in Lithuania. The pharmacy network is chosen for analysis due to the phenomenon that has appeared in the market, i.e., over the years decreasing trust in companies of one sector (pharmaceutical, in this case) has been unjustly identified with the situation in the other sector (pharmacy), which results in difficulties faced when building corporate reputation.
\end{abstract}

Keywords: Consumer Trust; Corporate Reputation; Reputation Dimensions; Pharmacy Network.

\section{Introduction}

Due to various crises in political, economic, and business environments, constantly decreasing corporate reputation and resulting low stakeholder trust increase economic and social uncertainty in the society. Insights offered by researchers and market research companies suggest that stakeholder trust rooted in good corporate reputation may ensure both short-term and long-term economic and social value of stakeholder relationships and help to survive in the economically and socially challenging situation of modern business. Nowadays the topic of the impact of corporate reputation on stakeholder trust has become extremely relevant in research. Researchers in the field of marketing and management mostly focus on the impact of corporate reputation on customer trust (CurrasPerez \& Keh, Xie, 2009; Park et al., 2012a; Sah \& Abdullah, 2016; Walsh \& Beatty, 2007; Walsh et al., 2013). In consumer research, the significance of corporate reputation to consumer trust is revealed through findings regarding the stability of purchase volume, retaining consumer market share, and development of consumer relationships. Other stakeholder studies emphasize the attempt to avoid economic decline, to survive crises (Verhoeven et al., 2012), and to maintain good performance results (Siano et al., 2010; Tong, 2015) using the established corporate reputation. There are few studies in the literature that deal with the impact of corporate reputation on consumer trust and that consider the multidimensional nature of corporate reputation and the variety of trust types (in comparison to the number of studies performed by global market research companies in the field). Therefore, there is a need not only to determine the impact of corporate reputation on trust that consumers as the major stakeholders put in an organization, but also to reveal which dimensions of corporate reputation condition certain type of consumer trust.

Therefore, the scientific problem dealt with in the article is defined by the following questions: What is the impact of corporate reputation on consumer trust? Which dimensions of corporate reputation determine different types of consumer trust?

The aim of the article is to estimate the impact of corporate reputation on consumer trust and to determine which dimensions of corporate reputation affect different types of consumer trust. The research results are presented by using the method of comparative literature analysis and the data of quantitative research.

The paper is structured as follows: first, the study that reveals different types of consumer trust in the multidimensional context of the impact of corporate trust is introduced. Second, the part dealing with study results reveals empirical research findings which focus on the pharmacy sector and contribute to the development of trustbased consumer relationships in the companies operating in the sector. The conceptual framework of the impact of corporate reputation on consumer trust may be applied to practical activity of companies operating in various sectors. 
Conclusions are drawn in the last section of the paper. They present the main theoretical and empirical results that reveal the way corporate reputation dimensions affect customer trust in the case of the analysed sector. In addition, implications for future research are provided.

\section{Literature Review}

\section{Dimensions of Corporate Reputation}

Two decades ago, Fombrun \& van Riel (1997) claimed the analysis of corporate reputation to be chaotic and worthless. Barnett et al. (2006) and Maden et al. (2012) believed that such an approach developed because the researchers who analysed corporate reputation did not put enough effort to find one common definition of the concept, i.e., reputation was treated according to different researchers' approaches, and the search for one construct started much later. A comprehensive analysis of multiple scientific sources dealing with the topic of reputation (Maden et al., 2012; Keh \& Xie, 2009; Abratt \& Kleyn 2012; Siano et al., 2010; Peloza et al., 2012, etc.) leads to the conclusion that corporate reputation is a reflection of stakeholders, perception of an organization, their emotional response to the organization, information received through direct or indirect experience with the organization, and organization's past actions. Since different stakeholders have different attitudes to corporate reputation, it is considered to be a complex construct.

The review of corporate reputation dimensions used by market research and consulting companies in estimating corporate reputation and those mentioned in the literature reveals that all the considered dimensions of corporate reputation come down to six main ones identified by Fombrun et al. (2000): financial performance, vision and leadership, products and services, workplace environment, social responsibility, and emotional appeal. Later the reputation dimensions established by the author were subdivided into smaller subdimensions in the subsequent works of different researchers (Cravens et al., 2003; Fombrun et al., 2015; Hillenbrand \& Money, 2009; Maden et al., 2012; Olmedo-Cifuentes et al., 2014; Podnar et al., 2012; Schwaiger, 2004; Shamma, Hassan, 2009).

\section{Types of Trust}

Corporate reputation and stakeholder trust are interrelated. Trust analysis in the reviewed literature works is chaotic. Even the authors who investigate the same type of trust use different criteria for analysis. Laeequddin et al. (2010) state that trust depends on the context under investigation. When analysing trust in the context of a dynamic business environment, a variety of research approaches may be adopted, one of which is types of trust.

Types of trust express the origin and causality of trust. In sociology, trust is typically seen as quality-based and institutional trust. Social sciences approach trust as being calculus-based, knowledge-based, and identification-based (Stoecklin-Serino, 2009), and not so often as deterrencebased and relational-based (Dietz \& Hartog, 2006; Idrissou et al., 2013). A more in-depth analysis of these trust types revealed that they are all interrelated and may be analysed in a common context of building trust due to their complementarity which is shown through gradual transition of trust from one state to another.

The basis for stakeholder (including consumer) trust is three types of trust, i.e., calculus-based, knowledge-based, and identification-based trust (da Costa Hernandez, dos Santos, 2010; Lander et al., 2004):

1. Calculus-based trust is achieved through economic value the company creates for stakeholders; it is the relationship between benefits and costs for stakeholders.

2. Knowledge-based trust resultant from corporate reputation is based on information about organization's performance when interacting with stakeholders accumulated in the long term.

3. Identification-based trust is based on stakeholders' empathy for the organization. Having received certain information about the company and agreeing with its objectives, values, and identity, a stakeholder unconsciously desires to be a part of the company, merge with it, and finally it completely identifies with the company and achieves the highest level of trust.

According to Dietz \& Hartog (2006), Stoecklin-Serino (2009), all the three types of trust are related, i.e., one stems from the other. Dietz \& Hartog (2006), Lau \& Cobb (2010) claim that calculus-based trust that developed based on stakeholder's expectations is reinforced by information about organization, which subsequently leads to the second level of trust, i.e., knowledge-based trust is built. Dietz \& Hartog (2006), Idrissou et al. (2013) note that the real stakeholder trust starts with the development of knowledge-based trust. When calculus-based trust starts to transition into knowledgebased trust, it acquires the shape of emotional trust. Trust starts to be based not on some commonly known features of the company or stakeholder's motives, but on stakeholder's estimation of the company (Dietz \& Hartog, 2006). In the long term, knowledge-based trust evolves into the highest level of trust, i.e., identification-based trust. The stakeholder identifies itself with the organization and they start sharing the same interests, which determines full stakeholder's trust in the organization.

As the analysis of trust types has revealed, researchers most often follow three perspectives of approach to trust: calculus-based trust, knowledge-based trust, and identification-based trust. When an organization manages to combine the three major perspectives, it acquires the possibility to achieve strong and full consumer trust that expresses the relationship of interacting parties and helps the company to survive.

\section{A Conceptual Model of the Impact of Corporate Reputation on Key Consumer Trust in an Organization}

Many researchers emphasize that consumer trust is mostly related to the quality of products and services the organization provides. Walsh and Beatty (2007) and Walsh et al. (2009) proved that the quality of products and services is the principal criterion of consumer trust. Scientific literature often mentions the following criteria: financial stability of a company, customer orientation, company as a good employer, social and environmental responsibility. Terblanche (2014), Walsh \& Beatty (2007), Walsh et al. (2009) and Shahsavari \& Faryabi (2013) follow this approach. Since there are clear links between the criteria of consumer trust and the dimensions 
of corporate reputation (financial performance, product and services, workplace environment, and social responsibility), in what follows a more detailed description of the criteria is provided and their links with indicated corporate reputation dimensions are substantiated.

Financial stability of a company. Shahsavari \& Faryabi (2013), Terblanche (2014), Walsh \& Beatty (2007), Walsh et al. (2009) consider financial stability to be the main criterion for company's reliability and consumer trust and propose to analyze it in terms of organization's competence, solidity, profitability, vision, and potential. According to Shahsavari \& Faryabi (2013), the company that acts in a competent, stable, profitable, and viable way creates an image of a reliable company, which stimulates consumers to trust and become involved with the company. Terblanche (2014), Walsh \& Beatty (2007) maintain that company's reliability may be seen as a link between its financial stability and consumer trust.

Based on the results of theoretical and empirical research by Ruiz et al. (2014), Shahsavari \& Faryabi (2013), Terblanche (2014), Walsh \& Beatty (2007), Walsh et al. (2009), a conclusion is drawn that consumer trust is directly or indirectly influenced by company's financial stability which comprises stability, profitability, and viability of the organization. Consumer trust that is formed directly is characterized by perception or awareness that company acts in a stable, profitable, and viable way, whereas indirect impact of financial stability on consumer trust shows through consumers' perception of the organization as being trustworthy and reliable.

To summarize the theoretical analysis of company's financial stability as a criterion that affects consumer trust, it should be noted that financial stability is expressed through components that have conceptual similarity to the following indicators of good financial performance subdimension expressing the financial performance dimension of corporate reputation: low investment risk, competitive advantage (similar to company's stability dimension), profitability (similar to profitability dimension), and viability (similar to viability dimension).

Quality of products and services. Terblanche (2014) and Walsh \& Beatty (2007) maintain that quality of company's products and services includes consumers' perception that the organization offers innovative, quality products and services that keep it moving forward. According to Abdul et al. (2012), consumers see the quality of products and services in terms of different dimensions. The authors describe the quality of products in terms of two dimensions: 1) product attributes that correspond to specific consumer needs and 2) product reliability, absence of defects. This attitude may be considered as generic since it allows an easy and clear description of the way consumers assess products. However, previous research in the field provided more comprehensive and consistent approach to dimensions of product quality criterion. Up to now, researchers have based their work on the following major dimensions of product quality identified by Garvin (1984): performance, features, reliability, conformance, durability, serviceability, aesthetics, perceived quality (e.g., brand identity). Sebastianelli \& Tamimi (2002) divided these eight dimensions into three groups, the first one comprising durability, serviceability, and reliability; the second one consisting of conformance and performance; whereas perceived quality, aesthetics, and features were grouped into the third one. Sebastianelli \& Tamimi (2002) also explained that the first group of product quality dimensions allows consumers to avoid usage-related troubles (performs the function of trouble elimination), the second one reveals the purpose of a product (adaptability), whereas the third one is based on emotional appeal to the customers. It is important to note that the above-mentioned dimensions of product quality are also used by present-day researchers Cassia et al. (2015), Manning (2013), Walsh et al. (2013). Besides, these dimensions may be used when evaluating the quality of both products and services. In terms of services, Parasuraman, Berry, and Zeithaml (1991), Zeithaml, Berry, and Parasuraman (1993) (op cit Ganguli, Roy, 2013; Hussain et al., 2015; Zhou et al., 2009) identified five main dimensions of service quality: reliability (ability to provide service exactly as promised), tangibility (physical infrastructure, customer service, staff, and material resources should be identical to the ones promised in advertising, etc.), responsiveness (determination to help consumers and to provide timely service), assurance (knowledge and respect shown by employees, their ability to ensure trust and confidentiality), empathy (compassion, individual attention to each customer).

Based on four out of five main dimensions of service quality, Zhou et al. (2009) proved that service quality has impact on consumer trust. Eisingerich \& Bell (2008), Lien et al. (2014) and Park et al. (2012b) confirmed the influence of service quality on consumer trust, whereas Alan \& Kabadayi (2014) and Zehir et al. (2011) proved that service quality affects trust that consumers put in brand. Their studies confirmed that the quality of both products and services has impact on consumer trust.

Quality of products and services that affects consumer trust has conceptual similarity to the corporate reputation dimension of products and services, since the way products and services are perceived (in terms of durability, serviceability, reliability; conformance, performance; emotional appeal; reliability, tangibility, responsiveness, assurance, empathy) is very similar to the indicators of subdimension of corporate reputation dimension of products and services (company's products, customer orientation, innovation, and value). Durability, serviceability, and reliability of products are similar to the subdimensions of good quality of products and services, implementation of quality management systems, and innovations in the corporate reputation dimension of products and services. Product quality dimensions of conformance and performance correspond to the subdimensions of installation of product and service improvement programs and R\&D investment in the corporate reputation dimension of products and services. Finally, the dimensions of emotional appeal, reliability, tangibility, responsiveness, assurance, and empathy are similar to the subdimensions of attention to consumers and listening to their suggestions comprising the corporate reputation dimension of products and services.

Customer orientation. Customer orientation refers to company's ability to satisfy customer needs, to see them as a priority (Terblanche, 2014; Walsh, Beatty, 2007). According to Cross et al. (2007), Singh \& Koshy (2012), customer orientation is the means to increase consumer satisfaction, trust, and loyalty, based on which the company achieves higher profit and growth. With the aim to confirm that trust in company's employees affects consumer trust, 
Guenzi \& Georges (2010) conducted a study and found out that company's orientation towards consumers has a direct impact on their trust in the company's staff, which fosters consumer-company relationship in terms of purchase and word-of-mouth. Although the influence of consumer orientation on consumer trust has been proved, researchers still do not agree on the dimensions of the consumer orientation criterion used in measuring consumer trust.

Iacob (2014) and Singh \& Koshy (2012) presented the dimensions of consumer orientation which give priority to attention to consumers rather that product orientation and company's employees ability to present them adequately. According to Singh \& Koshy (2012), customer orientation means providing information to customers, identifying their needs and satisfying them, value creation, maintaining customer satisfaction, and developing long-term and mutually beneficial company-customer relationship. Scientists argue that three major dimensions that determine effective customer orientation are related to person, organization, and management. Although the dimensions related to organization and management are difficult to associate with customer orientation because of their direct link to certain aspects of company's human resources (e.g., organizational climate and culture, the role of employees) and organizational management (e.g., centralized decisionmaking, quality of relationships among different management levels, leadership style), staff as people may be considered the most important dimension of customer orientation since it is their effort, knowledge, skills, and personal qualities that determine how company-customer relationship and trust are established.

To summarize the approach of the above-mentioned authors, to achieve overall customer orientation, the role of employees in company's performance is still the major consideration. It may seem that the significance of employee dimension when striving for overall customer orientation is related to the corporate reputation dimension of workplace environment, yet in this case, when implementing customer orientation, the primary goal of the company is to provide product or service to consumers. Being an important part of customer orientation, company's employees make products and services available to consumers. Consequently, the key element in customer orientation is products and services represented, presented, and adapted to specific consumer needs by company's employees. Customer orientation may be claimed to refer to customer needs satisfaction achieved through overall employee honesty when presenting product to consumers, making them interested in it without pressure and manipulation of their feelings. Based on this rationale, it is possible to state that the customer orientation criterion used to measure consumer trust is similar to the subdimensions of attention to customers and listening to their suggestions that constitute the corporate reputation dimension of products and services.

Company as a good employer. The status of a company as a good employer refers to how company treats its employees, manages them properly, and develops employee competences (Terblanche, 2014; Walsh, Beatty, 2007). When analysing this criterion, a question arises whether it is really related to consumer trust rather than employee trust. To answer the question, we could refer to research undertaken by Shamma \& Hassan (2009) and the insights they gained. According to the researchers, human resources not only reflect an internal organizational environment, but they are also related to its performance results directly oriented towards customers such as product and service quality used to evaluate consumer trust. Cravens et al. (2003) argue that customers and other stakeholders trust in the organization only when its employees are loyal and satisfied with their employer. Scientists proved that good status of a company as employer has impact on consumer trust and loyalty and is a more important criterion than reliability and financial stability, product and service quality, as well as social and environmental responsibility. What is more, only customer orientation was identified as the criterion that has more influence on consumer trust than company being a good employer.

In the literature, there are only a few studies (Cravens et al., 2003; Shamma \& Hassan, 2009; Terblanche, 2014; Walsh, Beatty, 2007) that rather superficially discuss the impact of good employer status of an organization on consumer trust. It can be stated that the link between good employer status and consumer trust has not received sufficient attention in research. Therefore, when analysing this consumer trust criterion, it is relevant to use a more specific construct. One of such constructs is 'employer branding'.

The concept of employer branding focuses more on employees; it describes the qualities of a company as an employer to employees. Nevertheless, this concept also targets many other stakeholders including consumers. Backhaus \& Tikoo (2004), Berthon et al. (2005) maintain that employer branding not only shows functional, economic, or psychological value of an organization (as an employer) to employees but also reveals company's identity to numerous stakeholders. In other words, employer branding is related to company or product branding, i.e., a company consciously supports its employer branding through focus on employee welfare, which indirectly shows stakeholders that the company caring for its employees creates value to consumers through products and services provided by satisfied employees (Foster et al., 2010; Ruiz et al., 2014). According to Ruiz et al. (2014), Wilden et al. (2010) employer branding is a sign to consumers and other stakeholders that the company is to be respected and has a good reputation. Foster et al. (2010) suggest that consumers are a company's target group, whereas employees are intermediaries between a company (as an employer) and consumers. Despite the suggestion, employer branding receives more attention in the context of organizational relations research. Meeting employee expectations, ensuring their satisfaction and loyalty are perceived as a secondary result of employer branding targeted at consumers. This is the reason why researchers pay little attention to the impact employer branding has on consumers. Nonetheless, analysis of the literature in the field shows that employer branding can be seen as the only significant and major dimension of the good employer criterion used to measure consumer trust that focuses on ensuring consumer trust.

In order to enhance the presented insights, we could substantiate conceptual similarity between the good employer criterion and the subdimensions of organizational culture and human resources (comprising such indicators as environment reliability, following organizational culture, 
ability to attract and retain talented employees, take care of them and train them, good working conditions, employee satisfaction and motivation) that express the workplace environment dimension of corporate reputation.

Social and environmental responsibility. Social and environmental responsibility is described as company's ability to assume responsibility to society and environment (Terblanche, 2014; Walsh, Beatty, 2007). It should be noted that the criterion of social and environmental responsibility is not considered a priority in measuring consumer trust. Although some researchers, including Park et al., (2014), Semuel \& Chandra (2014), Tian et al., (2011) have justified the influence of social responsibility on consumer trust, the majority of researchers quite often distance themselves from the criterion in their analysis of consumer trust. What is more, many researchers question the impact of social and environmental responsibility on consumer trust. Having conducted a thorough study in USA, Great Britain, and Japan, Page \& Fearn (2005) concluded that an organization's responsibility to environment or society is important only if it does not increase the price of products or services: consumers do not agree to pay more just because the organization acts in a socially responsible way. In their study, Lacey and Kennett-Hensel (2010) denied the assumption that social responsibility enhances consumer trust. Even though Lin et al. (2011) and Stanaland et al. (2011) have determined that there is a positive statistically significant link between social responsibility and consumer trust, they did not analyse the impact of this criterion on consumer trust. Kang \& Hustvedt (2014) proved that social responsibility has a minor influence on consumer trust, yet it should not be considered a priority criterion in measuring consumer trust. On the other hand, research into the sectors of organic food and farming (Perrini et al., 2010; Pivato et $a l ., 2008)$ has proved the opposite, i.e., company's social responsibility has a considerable impact on consumer trust. Inconsistencies in research findings lead to a conclusion that the impact of social and environmental responsibility on consumer trust cannot be treated unilaterally as it also depends on the sector that is being analysed.

Even though there is no clear answer, there is conceptual similarity between the criterion of social and environmental responsibility and the corporate responsibility dimension of social responsibility that comprises indicators of social and environmental responsibility sub-dimensions such as honesty, transparency, and care for the environment, pollution reduction, responsible consumption, support and charity, commitment to local community.

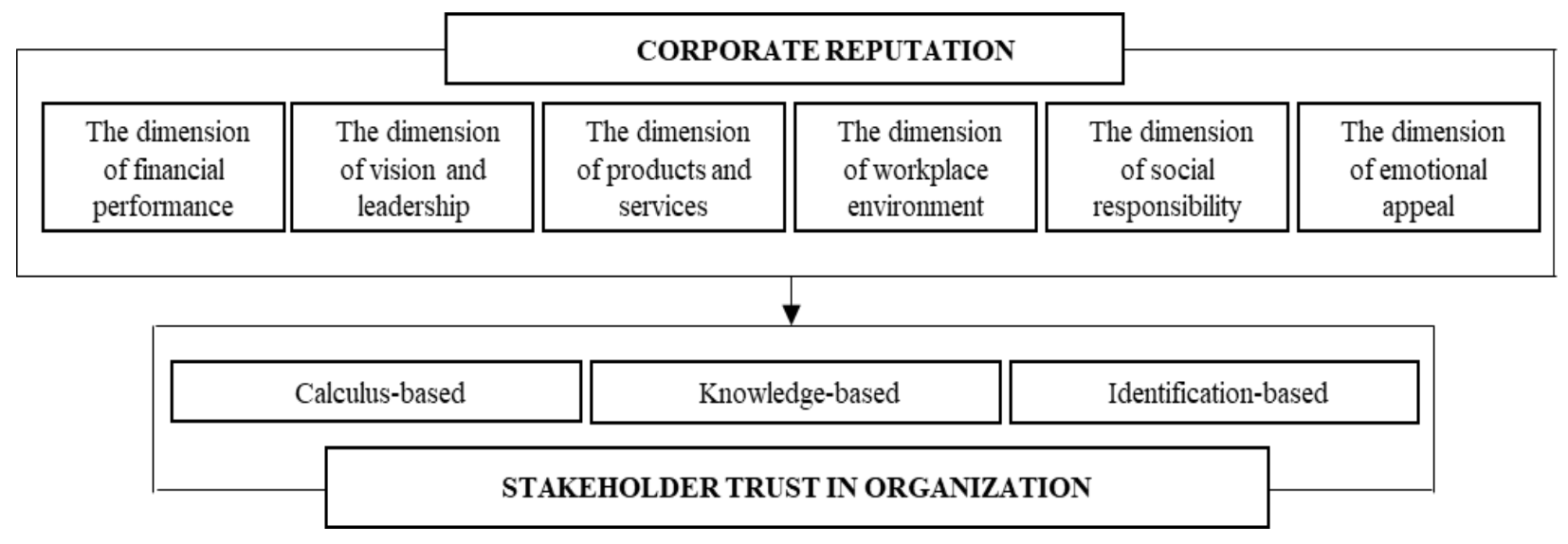

Figure 1. A conceptual model of the impact of corporate reputation on consumer trust in an organization

To summarize the discussed insights (see Figure 1), a theoretical insight is made that calculus-based, knowledgebased, and identification-based consumer trust is determined by financial stability of company, quality of products and services, customer orientation, good employer status, and social and environmental responsibility, which define subdimension indicators that constitute the corporate reputation dimensions of financial performance, products and services, workplace environment, and social responsibility.

\section{Methodology}

To substantiate the conceptual framework, quantitative research was carried out. A pharmacy network was chosen for the empirical study. Pharmacies are intricately linked to the pharmaceutical sector, which the public often identifies with pharmacies' activities. These sectors contribute to the country's economy and work with the same product pharmaceuticals, so pharmacies in society are equated with pharmaceutical companies. For this reason, public distrust concerning pharmacies is undeservedly increasing. Scepticism is also strengthened by the constant changes in legislation and their proposals for the pharmacy sector, which are often unfavourable to pharmacies. Customers of the largest pharmacy chains in Lithuania Camelia, were selected for the study. This network, despite the phenomenon of reputation matching, in 2016 and 2019, was recognized as one of the best reputation Lithuanian companies. Given the excellent reputation of this pharmacy network, it is considered appropriate to conduct empirical studies on the impact of an organization's reputation on consumer confidence in the organization, the results of which can be applied to the entire pharmacy sector.

The aim of quantitative research was to measure the impact of corporate reputation on different types of consumer trust in the case of pharmacy network. With regard to the aim of research, the following hypotheses of quantitative research have been put forward: 
H: Corporate reputation has a positive impact on consumer trust.

H1.1. Company's financial performance has a positive impact on calculus-based consumer trust.

H1.2. Company's financial performance has a positive impact on knowledge-based consumer trust.

H1.3. Company's financial performance has a positive impact on identification-based consumer trust.

H2.1. Company's vision and leadership has a positive impact on calculus-based consumer trust.

H2.2. Company's vision and leadership has a positive impact on knowledge-based consumer trust.

H2.3. Company's vision and leadership has a positive impact on identification-based consumer trust.

H3.1. Company's products and services have a positive impact on calculus-based consumer trust.

H3.2. Company's products and services have a positive impact on knowledge-based consumer trust.

H3.3. Company's products and services have a positive impact on identification-based consumer trust.

H4.1. Company's workplace environment has a positive impact on calculus-based consumer trust.

H4.2. Company's workplace environment has a positive impact on knowledge-based consumer trust.

H4.3. Company's workplace environment has a positive impact on identification-based consumer trust.

H5.1. Company's social responsibility has a positive impact on calculus-based consumer trust.

H5.2. Company's social responsibility has a positive impact on knowledge-based consumer trust.

H5.3. Company's social responsibility has a positive impact on identification-based consumer trust.

H6.1. Company's emotional appeal has a positive impact on calculus-based consumer trust.
H6.2. Company's emotional appeal has a positive impact on knowledge-based consumer trust.

H6.3. Company's emotional appeal has a positive impact on identification-based consumer trust.

To achieve the objectives of the quantitative research, the method of questionnaire survey was chosen. Nonprobability convenience sampling was chosen as a way to select the respondents, i.e., close to hand population was chosen following the convenience principle.

Sample justification. The size of consumer sample was calculated based on the sample size table created by Krejcie \& Morgan (1970) and used by researchers up to now when the size of representative population is approximate. In this case the total sampled population is all customers of the analysed pharmacy network (it is believed that the number is above one million since, according to the official data provided by the pharmacy network, this is the number of customers who are using loyalty cards of the pharmacy network). Thus, to conduct the study with $95 \%$ reliability and to obtain representative data, we had to survey 508 customers.

The instrument for quantitative study was developed based on a theoretical study of the impact of corporate reputation on stakeholder trust and the findings of a qualitative consumer study (see Table 1). To refine indicators (and their wording) used to measure the dimensions of corporate reputation, a quantitative research instrument has been developed based on a set of indicators to measure the reputation construct proposed by Fombrun $e t$ al. (2000) and Olmedo-Cifuentes et al. (2014). Questions that reflect generalized indicators for measuring corporate reputation in the quantitative research were formulated to assess how these indicators are perceived by stakeholders. After customers of the analysed pharmacy network had been interviewed, the questions in the research instrument and their wording were revised.

Table 1

A Research-Based Instrument for Measuring the Dimensions of Corporate Reputation and Trust

\begin{tabular}{|c|c|c|c|c|c|}
\hline \multirow[b]{2}{*}{ Construct } & \multicolumn{3}{|c|}{ Structure of the construct } & \multirow[b]{2}{*}{ Indicators } & \multirow[b]{2}{*}{ Authors } \\
\hline & $\begin{array}{c}\text { Groups of } \\
\text { dimensions }\end{array}$ & Dimensions & Subdimensions & & \\
\hline \multirow{12}{*}{$\begin{array}{l}\text { Corporate } \\
\text { reputation }\end{array}$} & \multirow{12}{*}{$\begin{array}{l}\text { Group of } \\
\text { functional } \\
\text { dimensions }\end{array}$} & \multirow{4}{*}{$\begin{array}{l}\text { Dimension of } \\
\text { financial } \\
\text { results }\end{array}$} & \multirow{4}{*}{$\begin{array}{l}\text { Good financial } \\
\text { results }\end{array}$} & The organization is profitable & \multirow{4}{*}{$\begin{array}{l}\text { Fombrun } \\
\text { et al. } \\
(2000)\end{array}$} \\
\hline & & & & The risk of investing in this organization is low & \\
\hline & & & & $\begin{array}{l}\text { The organization tends to work better than its } \\
\text { competitors }\end{array}$ & \\
\hline & & & & Organization has a growth prospect & \\
\hline & & \multirow{3}{*}{$\begin{array}{l}\text { Dimension of } \\
\text { vision and } \\
\text { leadership }\end{array}$} & $\begin{array}{l}\text { Business } \\
\text { strategy }\end{array}$ & $\begin{array}{l}\text { The organization knows the market opportunities and } \\
\text { uses them }\end{array}$ & \multirow{3}{*}{$\begin{array}{l}\text { Fombrun } \\
\text { et al. } \\
(2000)\end{array}$} \\
\hline & & & $\begin{array}{l}\text { Realization of } \\
\text { business } \\
\text { strategy }\end{array}$ & The organization is well led & \\
\hline & & & Leadership & The organization has a clear vision for the future & \\
\hline & & \multirow{5}{*}{$\begin{array}{l}\text { Dimension of } \\
\text { products and } \\
\text { services }\end{array}$} & \multirow[b]{2}{*}{ Product offer } & The organization offers quality products and services & \multirow[b]{2}{*}{$\begin{array}{l}\text { Fombrun } \\
\text { et al. } \\
(2000)\end{array}$} \\
\hline & & & & $\begin{array}{l}\text { The products and services offered by the } \\
\text { organization are characterized by an appropriate } \\
\text { price / value ratio }\end{array}$ & \\
\hline & & & \multirow{2}{*}{$\begin{array}{l}\text { Customer } \\
\text { orientation }\end{array}$} & $\begin{array}{l}\text { The interests of consumers are taken into account in } \\
\text { the organization }\end{array}$ & \multirow{2}{*}{$\begin{array}{l}\text { Proposed } \\
\text { by authors }\end{array}$} \\
\hline & & & & $\begin{array}{l}\text { The organization seeks to ensure long-term } \\
\text { relationships with consumers }\end{array}$ & \\
\hline & & & $\begin{array}{l}\text { Innovations and } \\
\text { value creation }\end{array}$ & $\begin{array}{l}\text { The products and services offered by the } \\
\text { organization are lagging behind competitors (the } \\
\text { reverse question) }\end{array}$ & $\begin{array}{l}\text { Fombrun } \\
\text { et al. } \\
(2000)\end{array}$ \\
\hline
\end{tabular}




\begin{tabular}{|c|c|c|c|c|c|}
\hline \multirow{15}{*}{ Construct } & \multicolumn{3}{|c|}{ Structure of the construct } & \multirow[b]{2}{*}{ Indicators } & \multirow{3}{*}{ Authors } \\
\hline & $\begin{array}{c}\text { Groups of } \\
\text { dimensions }\end{array}$ & Dimensions & Subdimensions & & \\
\hline & & & & $\begin{array}{l}\text { The organization offers advanced products and } \\
\text { services }\end{array}$ & \\
\hline & \multirow{9}{*}{$\begin{array}{l}\text { Group of } \\
\text { social } \\
\text { dimensions }\end{array}$} & \multirow{3}{*}{$\begin{array}{l}\text { Dimension of } \\
\text { workplace } \\
\text { environment }\end{array}$} & $\begin{array}{l}\text { Organizational } \\
\text { culture }\end{array}$ & The organization is properly managed & $\begin{array}{l}\text { Fombrun } \\
\text { et al. } \\
\text { (2000) }\end{array}$ \\
\hline & & & \multirow[b]{2}{*}{$\begin{array}{l}\text { Human } \\
\text { resources }\end{array}$} & An organization is an attractive place to work & \multirow{2}{*}{$\begin{array}{l}\text { Fombrun } \\
\text { et al. } \\
\text { (2000) }\end{array}$} \\
\hline & & & & $\begin{array}{l}\text { The organization has brought together a network of } \\
\text { good employees }\end{array}$ & \\
\hline & & \multirow{6}{*}{$\begin{array}{l}\text { Dimension of } \\
\text { social } \\
\text { responsibility }\end{array}$} & \multirow{2}{*}{$\begin{array}{l}\text { Fair, ethical } \\
\text { performance }\end{array}$} & $\begin{array}{l}\text { The organization ensures high quality goods and } \\
\text { services to customers }\end{array}$ & \multirow{2}{*}{$\begin{array}{l}\text { Proposed } \\
\text { by authors }\end{array}$} \\
\hline & & & & The pricing of goods in this organization is fair & \\
\hline & & & \multirow{4}{*}{$\begin{array}{l}\text { Social and } \\
\text { environmental } \\
\text { responsibility }\end{array}$} & The organization supports public initiatives & \multirow{3}{*}{$\begin{array}{l}\text { Fombrun } \\
\quad \text { et al. } \\
(2000)\end{array}$} \\
\hline & & & & $\begin{array}{l}\text { The organization behaves in an environmentally } \\
\text { responsible manner }\end{array}$ & \\
\hline & & & & $\begin{array}{l}\text { The organization maintains high standards of human } \\
\text { behaviour }\end{array}$ & \\
\hline & & & & $\begin{array}{l}\text { Organization provides suitable working conditions } \\
\text { for employees }\end{array}$ & $\begin{array}{l}\text { Proposed } \\
\text { by authors }\end{array}$ \\
\hline & \multirow{3}{*}{$\begin{array}{l}\text { Group of } \\
\text { expressive } \\
\text { dimensions }\end{array}$} & \multirow{3}{*}{$\begin{array}{l}\text { Dimension of } \\
\text { emotional } \\
\text { appeal }\end{array}$} & \multirow{3}{*}{$\begin{array}{c}\text { Emotional } \\
\text { attractiveness }\end{array}$} & $\begin{array}{l}\text { My emotions in terms of this organization are } \\
\text { positive }\end{array}$ & \multirow{3}{*}{$\begin{array}{l}\text { Fombrun } \\
\text { et al. } \\
(2000)\end{array}$} \\
\hline & & & & I admire and respect this organization & \\
\hline & & & & I trust this organization & \\
\hline \multirow{7}{*}{$\begin{array}{l}\text { Consumer } \\
\text { trust }\end{array}$} & \multirow{7}{*}{\multicolumn{2}{|c|}{ Dimension of trust }} & \multirow{3}{*}{$\begin{array}{l}\text { Calculus-based } \\
\text { trust }(\mathrm{CB})\end{array}$} & $\begin{array}{l}\text { I always expect the prices of this pharmacy network } \\
\text { to be lower than the prices of others }\end{array}$ & \multirow{7}{*}{$\begin{array}{c}\text { Da Costa } \\
\text { Hernandez } \\
\text { \& dos } \\
\text { Santos } \\
(2010)\end{array}$} \\
\hline & & & & $\begin{array}{l}\text { I always expect that buying from this pharmacy } \\
\text { network will be more convenient than buying from } \\
\text { most others }\end{array}$ & \\
\hline & & & & $\begin{array}{l}\text { I always expect the commercial terms of the } \\
\text { pharmacy network to be more favourable than those } \\
\text { offered by most others }\end{array}$ & \\
\hline & & & \multirow{2}{*}{$\begin{array}{l}\text { Knowledge- } \\
\text { based trust } \\
\quad(\mathrm{KB})\end{array}$} & $\begin{array}{l}\text { Most of my previous experiences with this pharmacy } \\
\text { network were positive }\end{array}$ & \\
\hline & & & & $\begin{array}{l}\text { Most of the times I purchased from this pharmacy } \\
\text { network I had no problems }\end{array}$ & \\
\hline & & & \multirow{2}{*}{$\begin{array}{c}\text { Identification- } \\
\text { based trust (IB) }\end{array}$} & I have great respect for this pharmacy network & \\
\hline & & & & $\begin{array}{l}\text { I feel happy about buying from this pharmacy } \\
\text { network }\end{array}$ & \\
\hline
\end{tabular}

Data collection. Quantitative research was conducted on May to June 2019. When performing the survey, 270 paper questionnaires had been distributed and 233 were received back. In addition, approximately 260 requests to fill in electronic questionnaires and to share the link to the questionnaire in social networks, among personal acquaintances had been sent and 350 were received. The total of 583 questionnaires had been completed, 75 of which did not meet the requirements for filling in the questionnaire or were filled in incorrectly (e.g., marking the same number on the scale 1 to 5 in all answers). Therefore 508 questionnaires were used in further analysis.

Methodology for data analysis. Quantitative research data coding and analysis were performed using SPSS 23.0 statistical data analysis platform, package $R$.

Testing questionnaire reliability. To prove the reliability of research findings, questionnaire reliability was tested when measuring internal consistency between the dimensions of corporate reputation and the types of consumer trust, i.e., Cronbach's alpha coefficient. Table 2 presents the results of analysis of internal consistency among variables in consumer survey questionnaires.
Table 2

Results of Internal Consistency Analysis of Variables used in Consumer Survey Questionnaires

\begin{tabular}{|c|c|c|}
\hline Variable & $\begin{array}{c}\text { Number of } \\
\text { indicators for } \\
\text { the variables }\end{array}$ & $\begin{array}{c}\text { Coefficients of } \\
\text { internal consistency } \\
\text { (Cronbach's alpha) }\end{array}$ \\
\hline $\begin{array}{c}\text { Corporate } \\
\text { reputation }\end{array}$ & 25 & 0,925 Sig. 0,000 \\
\hline Trust & 7 & 0,893 Sig. 0,000 \\
\hline $\begin{array}{c}\text { All questionnaire } \\
\text { variables }\end{array}$ & 55 & 0,893 Sig. 0,000 \\
\hline
\end{tabular}

Cronbach's alpha coefficients of the analysed variables satisfied the set requirements. Thus, it is stated that the groups of variable indicators are consistent and the research questionnaire may be considered reliable.

Validity of constructs has been measured via factor analysis. The analysis was used to test validity of indicators for corporate reputation variable and that of indicators for types of consumer trust variable, after the internal consistency of the variables had been tested. The results of factor analysis of the variables are presented in what follows. 


\section{Results}

\section{Results of Factor Analysis}

Considering the requirements for measurement indicators applied to factor analysis, we claim that indicators of four dimensions of corporate reputation (i.e., vision and leadership, workplace environment, social responsibility, and emotional appeal) are completely consistent. Indicators referring to all three types of trust are also consistent. When performing factor analysis of two other corporate reputation dimensions (i.e., financial performance and products and services), variables for testing indicator validity were noticed to deviate from norms, which resulted in performing the following:

- Correlation analysis of indicators of financial performance dimension following the methodology for calculating Spearman's correlation coefficient used in the case of non-normal data distribution. Correlation analysis revealed that indicator $\mathrm{CR}^{\mathrm{FR} 2}$ has very weak correlation with indicator $\mathrm{CR}^{\mathrm{FR} 3}$ (Spearman's correlation coefficient 0.086, when $p=0.055$ ). Based on the obtained results, indicator $\mathrm{CR}^{\mathrm{FR} 2}$ was eliminated from further analysis, and factor analysis of indicators constituting the financial performance dimension of corporate reputation was repeated. After factor analysis had been repeated and internal consistency of the indicators of the financial performance dimension had been tested, one more indicator $\left(\mathrm{CR}^{\mathrm{FR} 1}\right)$ was eliminated from further analysis since its coefficient of corrected correlation (0.697) was higher than Cronbach's alpha coefficient of the factor (0.593). Having eliminated $\mathrm{CR}^{\mathrm{FR} 1}$, we performed factor analysis of the indicators constituting the financial performance dimension of corporate reputation for the third time. Estimation of internal consistency among indicators of the financial performance dimension led to the conclusion that the indicator requirements for factor analysis had been met, i.e., the indicators were consistent among themselves.

- Correlation analysis of factors constituting indicators, which showed that indicator $\mathrm{C}^{\mathrm{RPS} 1}$ weakly correlates with other factor indicators (values of Spearman's correlation coefficient vary from 0.214 to 0.307 ). Based on the above-mentioned arguments, indicator $\mathrm{C}^{\mathrm{RPS} 1}$ was eliminated from further analysis, and factor analysis of the indicators constituting the products and services dimension of corporate reputation was repeated.

The results of factor analysis are presented in Table 3 .

Table 3

Results of Factor Analysis of Corporate Reputation Dimensions and Consumer Trust Types

\begin{tabular}{|c|c|c|c|c|c|c|c|}
\hline $\begin{array}{l}\text { Number } \\
\text { of factors }\end{array}$ & $\begin{array}{c}\text { Code of } \\
\text { indicators }\end{array}$ & $\begin{array}{c}\text { Factor } \\
\text { weights }\end{array}$ & $\begin{array}{l}\text { Total Variance } \\
\text { Explained, \% }\end{array}$ & $\begin{array}{c}\text { Cronbach's } \\
\text { Alpha }\end{array}$ & $\begin{array}{l}\text { Cronbach's } \\
\text { Alpha if } \\
\text { Item } \\
\text { Deleted }\end{array}$ & $\begin{array}{c}\text { Kaiser-Meyer-Olkin } \\
\text { Measure of Sampling } \\
\text { Adequacy }\end{array}$ & $\begin{array}{l}\text { Bartlett's } \\
\text { Test of } \\
\text { sphericity }\end{array}$ \\
\hline \multicolumn{8}{|c|}{ Financial results dimension of corporate reputation } \\
\hline \multirow{2}{*}{$\begin{array}{l}\text { One } \\
\text { factor }\end{array}$} & \multirow{2}{*}{$\begin{array}{l}\mathrm{CR}^{\mathrm{FR} 3} \\
\mathrm{CR}^{\mathrm{FR} 4} \\
\end{array}$} & 0,876 & \multirow{2}{*}{76,77} & \multirow{2}{*}{0,697} & - & \multirow{2}{*}{0,500} & \multirow{2}{*}{0,000} \\
\hline & & 0,876 & & & & & \\
\hline \multicolumn{8}{|c|}{ Vision and leadership dimension of corporate reputation } \\
\hline \multirow{3}{*}{$\begin{array}{l}\text { One } \\
\text { factor }\end{array}$} & \multirow{3}{*}{$\begin{array}{l}\mathrm{CR}^{\mathrm{VL} 1} \\
\mathrm{CR}^{\mathrm{VL} 2} \\
\mathrm{CR}^{\mathrm{VL} 3}\end{array}$} & 0,826 & \multirow{3}{*}{67,41} & \multirow{3}{*}{0,758} & 0,671 & \multirow{3}{*}{0,673} & \multirow{3}{*}{0,000} \\
\hline & & 0,861 & & & 0,609 & & \\
\hline & & 0,774 & & & 0,747 & & \\
\hline \multicolumn{8}{|c|}{ Products and services dimension of corporate reputation } \\
\hline \multirow{5}{*}{$\begin{array}{l}\text { One } \\
\text { factor }\end{array}$} & \multirow{5}{*}{$\begin{array}{l}\mathrm{CR}^{\mathrm{PS} 2} \\
\mathrm{CR}^{\mathrm{PS} 3} \\
\mathrm{CR}^{\mathrm{PS} 4} \\
\mathrm{CR}^{\mathrm{PS} 5} \\
\mathrm{CR}^{\mathrm{PS} 6}\end{array}$} & 0,755 & \multirow{5}{*}{57,24} & \multirow{5}{*}{0,815} & 0,782 & \multirow{5}{*}{0,749} & \multirow{5}{*}{0,000} \\
\hline & & 0,757 & & & 0,781 & & \\
\hline & & 0,760 & & & 0,776 & & \\
\hline & & 0,776 & & & 0,767 & & \\
\hline & & 0,734 & & & 0,786 & & \\
\hline \multicolumn{8}{|c|}{ Workplace environment dimension of corporate reputation } \\
\hline \multirow{3}{*}{$\begin{array}{l}\text { One } \\
\text { factor }\end{array}$} & $\mathrm{CR}^{\mathrm{WE} 1}$ & 0,776 & \multirow{3}{*}{63,94} & \multirow{3}{*}{0,718} & 0,664 & \multirow{3}{*}{0,676} & \multirow{3}{*}{0,000} \\
\hline & $\mathrm{CR}^{\mathrm{WE} 2}$ & 0,818 & & & 0,599 & & \\
\hline & $\mathrm{CR}^{\mathrm{WE} 3}$ & 0,803 & & & 0,621 & & \\
\hline \multicolumn{8}{|c|}{ Social responsibility dimension of corporate reputation } \\
\hline \multirow{6}{*}{$\begin{array}{l}\text { One } \\
\text { factor }\end{array}$} & $\mathrm{CR}^{\mathrm{SR} 1}$ & 0,717 & & & 0,756 & & \\
\hline & $\mathrm{CR}^{\mathrm{SR} 2}$ & 0,722 & & & 0,754 & & \\
\hline & $\mathrm{CR}^{\mathrm{SR} 3}$ & 0,716 & 4018 & 0701 & 0,756 & 0812 & ח \\
\hline & $\mathrm{CR}^{\mathrm{SR} 4}$ & 0,685 & 49,18 & 0,191 & 0,762 & 0,812 & 0,000 \\
\hline & $\mathrm{CR}^{\mathrm{SR} 5}$ & 0,719 & & & 0,751 & & \\
\hline & $\mathrm{CR}^{\mathrm{SR} 6}$ & 0,645 & & & 0,777 & & \\
\hline & & Social a & environmental r & onsibility dim & sion of corpo & reputation & \\
\hline & $\mathrm{CR}^{\mathrm{SER} 1}$ & 0,849 & & & 0,832 & & \\
\hline factor & $\mathrm{CR}^{\mathrm{SER} 2}$ & 0,888 & 76,80 & 0,849 & 0,771 & 0,722 & 0,000 \\
\hline & $\mathrm{CR}^{\mathrm{SER} 3}$ & 0,892 & & & 0,764 & & \\
\hline & & & Typ & f calculus-base & trust & & \\
\hline & $\mathrm{T}^{\mathrm{CB} 1}$ & 0,888 & & & 0,825 & & \\
\hline factor & $\mathrm{T}^{\mathrm{CB} 2}$ & 0,870 & 79,49 & 0,871 & 0,851 & 0,725 & 0,000 \\
\hline & $\mathrm{T}^{\mathrm{CB} 3}$ & 0,916 & & & 0,775 & & \\
\hline
\end{tabular}




\begin{tabular}{|c|c|c|c|c|c|c|c|}
\hline $\begin{array}{l}\text { Number } \\
\text { of factors }\end{array}$ & $\begin{array}{c}\text { Code of } \\
\text { indicators }\end{array}$ & $\begin{array}{c}\text { Factor } \\
\text { weights }\end{array}$ & $\begin{array}{l}\text { Total Variance } \\
\text { Explained, \% }\end{array}$ & $\begin{array}{c}\text { Cronbach's } \\
\text { Alpha }\end{array}$ & $\begin{array}{l}\text { Cronbach's } \\
\text { Alpha if } \\
\text { Item } \\
\text { Deleted }\end{array}$ & $\begin{array}{c}\text { Kaiser-Meyer-Olkin } \\
\text { Measure of Sampling } \\
\text { Adequacy }\end{array}$ & $\begin{array}{c}\text { Bartlett's } \\
\text { Test of } \\
\text { sphericity }\end{array}$ \\
\hline \multicolumn{8}{|c|}{ Type of knowledge-based trust } \\
\hline \multirow{2}{*}{$\begin{array}{c}\text { One } \\
\text { factor }\end{array}$} & \multirow{2}{*}{$\begin{array}{l}\mathrm{T}^{\mathrm{KB} 1} \\
\mathrm{~T}^{\mathrm{KB} 2}\end{array}$} & 0,900 & \multirow{2}{*}{80,95} & \multirow{2}{*}{0,765} & - & \multirow{2}{*}{0,500} & \multirow{2}{*}{0,000} \\
\hline & & 0,900 & & & - & & \\
\hline \multicolumn{8}{|c|}{ Type of identification-based trust } \\
\hline \multirow{2}{*}{$\begin{array}{l}\text { One } \\
\text { factor }\end{array}$} & \multirow{2}{*}{$\begin{array}{l}\mathrm{T}^{\mathrm{IB} 1} \\
\mathrm{~T}^{\mathrm{IB} 2}\end{array}$} & 0,932 & \multirow{2}{*}{86,90} & \multirow{2}{*}{0,847} & - & \multirow{2}{*}{0,500} & \multirow{2}{*}{0,000} \\
\hline & & 0,932 & & & - & & \\
\hline
\end{tabular}

\section{Results of Regression Analysis}

According to Cekanavicius \& Murauskas (2014), independent variables in the regression model should correlate with the dependent variable. Table 4 shows that all correlations between dependent and independent variables in the case of consumer research are positive and statistically significant.

Table 4

Correlations between Dependent and Independent Variables in the Consumer Research

\begin{tabular}{|c|l|c|c|c|c|c|c|c|}
\hline \multicolumn{2}{|c|}{} & $\mathbf{C R}$ & $\mathbf{C R}^{\mathbf{F R}}$ & $\mathbf{C R}^{\mathbf{V L}}$ & $\mathbf{C R}^{\mathbf{P S}}$ & $\mathbf{C R}^{\mathbf{W E}}$ & $\mathbf{C R}^{\text {SR }}$ & $\mathbf{C R}^{\text {SER }}$ \\
\hline \multirow{2}{*}{$\mathrm{T}$} & $\begin{array}{l}\text { Pearson } \\
\text { correlation }\end{array}$ & 0,777 & - & - & - & - & - & - \\
\cline { 2 - 9 } & Sig. (1-tailed) & 0,000 & - & - & - & - & - & - \\
\hline \multirow{2}{*}{$\mathrm{T}^{\mathrm{CB}}$} & $\begin{array}{l}\text { Pearson } \\
\text { correlation }\end{array}$ & - & 0,377 & 0,387 & 0,563 & 0,439 & 0,471 & 0,508 \\
\cline { 2 - 10 } & Sig. (1-tailed) & - & 0,000 & 0,000 & 0,000 & 0,000 & 0,000 & 0,000 \\
\hline \multirow{2}{*}{$\mathrm{T}^{\mathrm{KB}}$} & $\begin{array}{l}\text { Pearson } \\
\text { correlation }\end{array}$ & - & 0,421 & 0,464 & 0,613 & 0,496 & 0,510 & 0,605 \\
\cline { 2 - 10 } & Sig. (1-tailed) & - & 0,000 & 0,000 & 0,000 & 0,000 & 0,000 & 0,000 \\
\hline \multirow{2}{*}{$\mathrm{T}^{\mathrm{IB}}$} & $\begin{array}{l}\text { Pearson } \\
\text { correlation }\end{array}$ & - & 0,482 & 0,441 & 0,594 & 0,482 & 0,558 & 0,641 \\
\cline { 2 - 10 } & Sig. (1-tailed) & - & 0,000 & 0,000 & 0,000 & 0,000 & 0,000 & 0,000 \\
\hline
\end{tabular}

Table 5 presents validation results of regression models considering the impact of corporate reputation on consumer trust and the impact of the dimensions of corporate reputation on calculus-based, knowledge-based, and identification-based consumer trust.

Table 5

Results of Regression Model Testing: the Impact of Corporate Reputation on Consumer Trust and the Impact of Corporate Reputation Dimensions on Calculus-Based, Knowledge-Based, and Identification-Based Consumer Trust

\begin{tabular}{|c|c|c|c|c|c|c|c|c|c|c|}
\hline 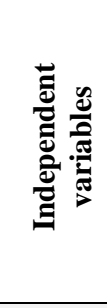 & 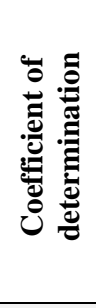 & 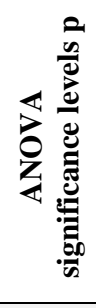 & 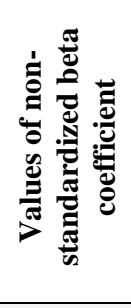 & 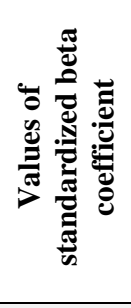 & 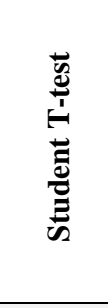 & 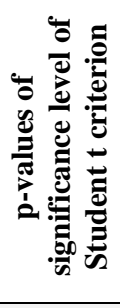 & 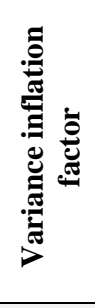 & $\begin{array}{l}\frac{\ddot{\theta}}{0} \\
\frac{0}{0}\end{array}$ & 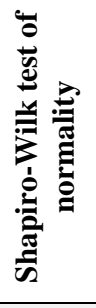 & 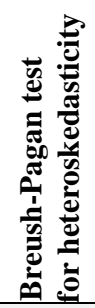 \\
\hline \multicolumn{11}{|c|}{ Regression model I (independent variable - trust $(\mathrm{T})$ ) } \\
\hline $\mathrm{CR}$ & 0,603 & 0,000 & 0,306 & 0,777 & 25,810 & 0,000 & 1,000 & $\begin{array}{c}\text { Min. } \\
0,000 \\
\text { Max. } \\
0,085 \\
\text { Vid. } \\
0,003\end{array}$ & 0,042 & 0,138 \\
\hline \multicolumn{11}{|c|}{ Regression model II (independent variable - calculus-based trust $\left(\mathrm{T}^{\mathrm{CB}}\right)$ ) } \\
\hline \multirow{6}{*}{$\begin{array}{l}\mathrm{CR}^{\mathrm{FR}} \\
\mathrm{CR}^{\mathrm{VL}} \\
\mathrm{CR}^{\mathrm{PS}} \\
\mathrm{CR}^{\mathrm{WE}} \\
\mathrm{CR}^{\mathrm{SR}} \\
\mathrm{CR}^{\mathrm{SER}}\end{array}$} & \multirow{6}{*}{0,362} & \multirow{6}{*}{0,000} & 0,153 & 0,128 & 2,226 & 0,027 & 1,672 & \multirow{6}{*}{$\begin{array}{c}\text { Min. } \\
0,000 \\
\text { Max. } \\
0,070 \\
\text { Vid. } \\
0,004\end{array}$} & \multirow{6}{*}{0,001} & \multirow{6}{*}{0,929} \\
\hline & & & $-0,028$ & $-0,032$ & $-0,477$ & 0,634 & 2,213 & & & \\
\hline & & & 0,168 & 0,325 & 4,623 & 0,000 & 2,529 & & & \\
\hline & & & 0,044 & 0,049 & 0,687 & 0,492 & 2,499 & & & \\
\hline & & & 0,043 & 0,085 & 1,193 & 0,234 & 2,602 & & & \\
\hline & & & 0,126 & 0,161 & 2,371 & 0,018 & 2,260 & & & \\
\hline
\end{tabular}




\begin{tabular}{|c|c|c|c|c|c|c|c|c|c|c|}
\hline 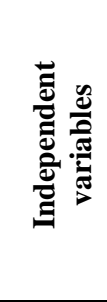 & 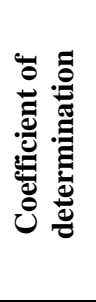 & 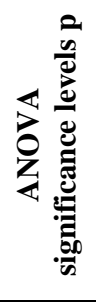 & 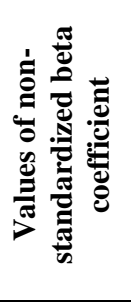 & 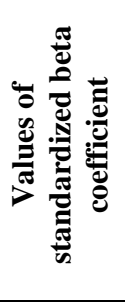 & 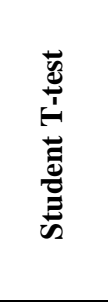 & 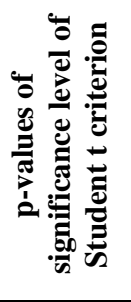 & 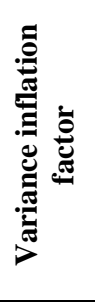 & $\begin{array}{l}\ddot{8} \\
\frac{8}{8}\end{array}$ & 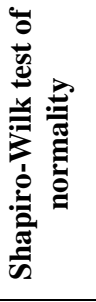 & 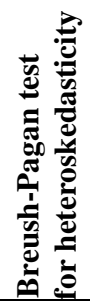 \\
\hline \multirow{6}{*}{$\begin{array}{l}\mathrm{CR}^{\mathrm{FR}} \\
\mathrm{CR}^{\mathrm{VL}} \\
\mathrm{CR}^{\mathrm{PS}} \\
\mathrm{CR}^{\mathrm{WE}} \\
\mathrm{CR}^{\mathrm{SR}} \\
\mathrm{CR}^{\mathrm{SER}} \\
\end{array}$} & \multirow{6}{*}{0,459} & \multirow{6}{*}{0,000} & 0,050 & 0,074 & 1,508 & 0,132 & 1,691 & \multirow{6}{*}{$\begin{array}{c}\text { Min. } \\
0,000 \\
\text { Max. } \\
0,059 \\
\text { Vid. } \\
0,003\end{array}$} & \multirow{6}{*}{0,000} & \multirow{6}{*}{0,576} \\
\hline & & & 0,038 & 0,073 & 1,334 & 0,183 & 2,130 & & & \\
\hline & & & 0,101 & 0,317 & 5,394 & 0,000 & 2,432 & & & \\
\hline & & & 0,026 & 0,049 & 0,835 & 0,404 & 2,420 & & & \\
\hline & & & $-0,001$ & $-0,004$ & $-0,064$ & 0,949 & 2,609 & & & \\
\hline & & & 0,132 & 0,293 & 5,094 & 0,000 & 2,335 & & & \\
\hline \multicolumn{11}{|c|}{ Regression model IV (independent variable - identification-based trust $\left(\mathrm{T}^{\mathrm{IB}}\right)$ ) } \\
\hline \multirow{6}{*}{$\begin{array}{l}\mathrm{CR}^{\mathrm{FR}} \\
\mathrm{CR}^{\mathrm{VL}} \\
\mathrm{CR}^{\mathrm{PS}} \\
\mathrm{CR}^{\mathrm{WE}} \\
\mathrm{CR}^{\mathrm{SR}} \\
\mathrm{CR}^{\mathrm{SER}}\end{array}$} & \multirow{6}{*}{0,511} & \multirow{6}{*}{0,000} & 0,172 & 0,220 & 3,915 & 0,000 & 1,614 & \multirow{6}{*}{$\begin{array}{c}\text { Min. } \\
0,000 \\
\text { Max. } \\
0,062 \\
\text { Vid. } \\
0,005\end{array}$} & \multirow{6}{*}{0,174} & \multirow{6}{*}{0,009} \\
\hline & & & $-0,032$ & $-0,062$ & $-0,964$ & 0,336 & 2,113 & & & \\
\hline & & & 0,057 & 0,169 & 2,485 & 0,014 & 2,352 & & & \\
\hline & & & 0,032 & 0,057 & 0,898 & 0,370 & 2,033 & & & \\
\hline & & & 0,053 & 0,162 & 2,445 & 0,015 & 2,229 & & & \\
\hline & & & 0,190 & 0,334 & 5,165 & 0,000 & 2,133 & & & \\
\hline
\end{tabular}

The coefficients of determination obtained when testing all four regression models are higher than 0.2 , which shows that the models are suitable for regression analysis. Independent variables in the models explain 60.3, 36.2, 45.9, and 51.1 per cent dispersion of a dependent variable. ANOVA significance levels show that all models contain at least one regression on which calculus-based, knowledgebased, and identification-based consumer trust depends.

Values of standardized beta coefficient show the following:

1. Company's products and services (followed by emotional appeal and financial performance) have the highest impact on calculus-based consumer trust.

2. Knowledge-based consumer trust is mostly affected by company's products and services and slightly less by emotional appeal.

3. Identification-based consumer trust is most influenced by emotional appeal, followed by financial performance, products and services, and social responsibility (in decreasing order).

Having reviewed p-values of significance level of Student $t$ criterion, one could notice the following:

1. In the case of first regression model testing, corporate reputation may be considered a statistically significant regression in consumer trust.

2. In the case of second regression model testing, the corporate reputation dimensions of products and services, emotional appeal, and financial performance may be considered statistically significant regression for calculusbased consumer trust. Other dimensions are not statistically significant regression.

3. In the case of third regression model testing, the corporate reputation dimensions of emotional appeal and products and services may be considered statistically significant regression for knowledge-based consumer trust. Other dimensions are not statistically significant regression.

4. In the case of fourth regression model testing, the corporate reputation dimensions of emotional appeal, products and services, financial performance, and social responsibility may be considered statistically significant regression for identification-based consumer trust. Other dimensions are not statistically significant regression.

The regression models may be considered suitable, yet it should be emphasized that statistical significance deviation of some independent variables from norms may be conditioned by non-normal distribution of residual standard error. With reference to the obtained results of consumer research, it is stated that hypotheses H, H1.1, H1.3, H3.1, H3.2, H3.3, H5.3, H6.1, H6.2, H6.3 have been confirmed after statistical significance of regression for consumer trust they contain was proved, whereas hypotheses H1.2, H2.1, H2.2, H2.3, H4.1, H4.2, H4.3, H5.1, H5.2 have not been proved.

Empirical consumer research revealed that the dimensions of products and services and emotional appeal have an impact on all types of consumer trust in the analysed pharmacy network. Apart from these two corporate reputation dimensions, financial performance has a positive impact on calculus-based consumer trust, while financial performance and social responsibility affect identificationbased consumer trust. Previous theoretical knowledge that consumer trust depends both on tangible (financial performance, products and services) and intangible (workplace environment, social responsibility) dimensions can be supplemented with one additional insight that company's emotional appeal is not only an important proof of company's identity but it also is one the corporate reputation dimensions that affect consumer trust.

Positive impact of company's financial performance was noticed on calculus-based and identification-based consumer trust. The influence of calculus-based consumer trust may be explained by the ability of profitable and constantly expanding pharmacy network that invests in innovation and offers competitive products and services to provide the highest expected value to customers. Similar objectives that consumers and pharmacy network have may be the reason for identification-based consumer trust. Company's aspiration to be the best in terms of financial performance reveals great ambitions and simultaneously responds to consumers' need to get products and services of 
the highest quality. Knowledge-based consumer trust was not noticed most probably because consumers have limited access to detailed financial data of the pharmacy network.

Positive impact of company's products and services on consumer trust was obvious in the case of all three types of consumer trust in the analysed pharmacy network. One can assume that consumers trust the pharmacy network because of tangible value its products and services provide (quality, price), which satisfies expectations typical of calculus-based consumer trust. In addition, the trust is earned through information about quality of products provided to consumers (which promotes knowledge-based trust) and consumer-oriented products and services (which builds identification-based consumer trust).

It was determined that social responsibility of pharmacy network does not affect calculus-based and knowledge-based consumer trust. Some possible reasons for that may be the fact that social responsibility of the pharmacy network does not create direct value for customers (as in the case of companies operating in the organic food and farming sector), and just being aware of socially responsible actions of the pharmacy network does not have a direct impact on knowledge-based consumer trust. Positive impact of social responsibility on identification-based consumer trust may be explained by similarity between socially responsible activity of the pharmacy network and consumers' values, objectives, behaviour, and attitudes to certain issues.

Empirical research revealed that emotional appeal of the chosen pharmacy network is an important factor leading to all three types of consumer trust. Emotional appeal of pharmacy network is thought to affect calculus-based consumer trust because of emotional value of transactions (satisfaction and joy in saving money), knowledge-based consumer trust because of the attractive way to receive information about the company and positive previous experience, and identification-based trust because of 'cosy' and 'personal' identity attributed to the pharmacy network.

\section{Discussion and Conclusions}

This article theoretically revealed the notional similarity of consumer trust criteria presented in the scientific literature to the dimensions of the corporate reputation. First, this study makes additional contributions by clarifying the conceptualisation of 'corporate reputation'. Contradictory approaches to corporate reputation prevailing in the literature reveal different perspectives to its perception and to the definition of corporate reputation as a reflection of stakeholders' perception of an organization, their emotional response to the organization, information received through direct or indirect experience with the organization, and organization's past actions. Second, methodologically, the corporate reputation effect on customer trust was tested with actual consumers of the pharmacy network under investigation. Third, the research strengthened the substantiation of the corporate reputation as a factor of customer trust in the organisation, and allowed theoretically and empirically justify the influence of the corporate reputation on different types of consumer trust in the organization in the pharmacy network case. It should be emphasized that the findings of the empirical study, regardless of whether the research was conducted in a single pharmacy network, can be applied to the other sector as well.

After reviewing the empirical research results and comparing with the theoretical research findings, the dissonance between them and the research topics found in the scientific literature was seen. The main differences between theoretical and empirical research findings are that the research results touch different areas of interest: researchers, in contrast to the authors of the article, limited the relationship, significance, or influence of certain corporate reputation areas on consumer trust. These findings allow us to conclude that the results of this study have significantly complemented this field of research on the corporate reputation and consumer trust.

This study contributes to the literature by increasing our understanding of which dimensions of corporate reputation affect different types of consumer trust (Table 6).

Table 6

\section{Hypotheses Overview}

\begin{tabular}{|l|c|}
\hline \multicolumn{1}{|c|}{ Hypothesis } & Results \\
\hline $\begin{array}{l}\text { H: Corporate reputation has a positive } \\
\text { impact on consumer trust. }\end{array}$ & Supported \\
\hline $\begin{array}{l}\text { H1.1. Company's financial performance } \\
\text { has a positive impact on calculus-based } \\
\text { consumer trust. }\end{array}$ & Supported \\
\hline $\begin{array}{l}\text { H1.2. Company's financial performance } \\
\text { has a positive impact on knowledge-based } \\
\text { consumer trust. }\end{array}$ & Not supported \\
\hline $\begin{array}{l}\text { H1.3. Company's financial performance } \\
\text { has a positive impact on identification- } \\
\text { based consumer trust. }\end{array}$ & Supported \\
\hline $\begin{array}{l}\text { H2.1. Company's vision and leadership has } \\
\text { a positive impact on calculus-based } \\
\text { consumer trust. }\end{array}$ & Not supported \\
\hline $\begin{array}{l}\text { H2.2. Company's vision and leadership has } \\
\text { a positive impact on knowledge-based } \\
\text { consumer trust.. }\end{array}$ & Not supported \\
\hline $\begin{array}{l}\text { H2.3. Company's vision and leadership has } \\
\text { a positive impact on identification-based } \\
\text { consumer trust }\end{array}$ & Not supported \\
\hline $\begin{array}{l}\text { H3.1. Company's products and services } \\
\text { have a positive impact on calculus-based } \\
\text { consumer trust. }\end{array}$ & Supported \\
\hline $\begin{array}{l}\text { H3.2. Company's products and services } \\
\text { have a positive impact on knowledge-based } \\
\text { consumer trust. }\end{array}$ & Supported \\
\hline $\begin{array}{l}\text { H3.3. Company's products and services } \\
\text { have a positive impact on identification- } \\
\text { based consumer trust. }\end{array}$ & Supported \\
\hline $\begin{array}{l}\text { H4.1. Company's workplace environment } \\
\text { has a positive impact on calculus-based } \\
\text { consumer trust. }\end{array}$ & Not supported \\
\hline $\begin{array}{l}\text { H4.2. Company's workplace environment } \\
\text { has a positive impact on knowledge-based } \\
\text { consumer trust. }\end{array}$ & Not supported \\
\hline $\begin{array}{l}\text { H4.3. Company's workplace environment } \\
\text { has a positive impact on identification- } \\
\text { based consumer trust. }\end{array}$ & Not supported \\
\hline $\begin{array}{l}\text { H5.1. Company's social responsibility has a } \\
\text { positive impact on calculus-based consumer } \\
\text { trust. }\end{array}$ & Not supported \\
\hline
\end{tabular}




\begin{tabular}{|l|c|}
\hline \multicolumn{1}{|c|}{ Hypothesis } & Results \\
\hline $\begin{array}{l}\text { H5.2. Company's social responsibility has a } \\
\text { positive impact on knowledge-based } \\
\text { consumer trust. }\end{array}$ & Not supported \\
\hline $\begin{array}{l}\text { H5.3. Company's social responsibility has a } \\
\text { positive impact on identification-based } \\
\text { consumer trust. }\end{array}$ & Supported \\
\hline $\begin{array}{l}\text { H6.1. Company's emotional appeal has a } \\
\text { positive impact on calculus-based consumer } \\
\text { trust. }\end{array}$ & Supported \\
\hline $\begin{array}{l}\text { H6.2. Company's emotional appeal has a } \\
\text { positive impact on knowledge-based } \\
\text { consumer trust. }\end{array}$ & Supported \\
\hline $\begin{array}{l}\text { H6.3. Company's emotional appeal has a } \\
\text { positive impact on identification-based } \\
\text { consumer trust. }\end{array}$ & Supported \\
\hline
\end{tabular}

Empirical research explained that various corporate reputation dimensions have different effects on the expression of consumer trust types. This result is partially consistent with the work Walsh, Beatty (2007), Bennett, Gabriel (2001), Tong (2015). It should be noted that only Walsh, Beatty's (2007) study has attempted to influence the impact of an organization's reputation on consumer confidence in the organization in the context of several dimensions of the organization's reputation. Academics, discussing the expression of trust types by stakeholders, highlight the continuity of trust types, termed as their complementarity, revealed through the gradual transition of trust from one state to another. Without empirically verifying this tendency, it should be clarified that trust according to its typology can be evaluated for two purposes: to assess the degree of trust or to interpret trust more deeply - through its origin, causality. Empirical research using trust types did not aim to estimate the degree of consumer trust, considering that the evaluation of the type of trust is too primitive and difficult to justify a method for determining the degree of trust. The use of three types of trust in empirical research is based on the purpose to explain the origin of trust, see the cause and effect relationship between the antecedents used in the research (dimensions of corporate reputation), and the results of the research (expressions of trust). Based on the stated arguments, there is no need to study for explanations for the continuity of the expression of trust types, which has not been empirically revealed in the general context of consumer trust formation. The following is a summary of the empirical study results concerning the customers, explaining the empirical study's findings, noting that the analysis is interpretative due to the lack of scientific information to support the empirical study's findings.

Empirical research into the impact of corporate reputation on consumer trust proved that corporate reputation has a positive impact on consumer trust. This result is consistent with the works of Omar et al. (2009); Fatma et al. (2015); Walsh et al. (2009).

Omar et al. (2009) in theory, Fatma et al. (2015), Walsh et al. (2009) have shown empirically that stakeholder trust in the organization demonstrates the strength of corporate reputation and it is mean that corporate reputation has a positive impact to consumer trust.
After the influence of corporate reputation dimensions on certain type of consumer trust had been verified, the following conclusion was drawn:

- Financial performance, products and services, and emotional appeal positively affect calculus-based consumer trust in the chosen pharmacy network. The results of this study are in line with Ruiz et al. (2014), Terblanche (2014), Walsh and Beatty (2007), Walsh et al. (2009), whose research concludes that the organization's financial stability directly or indirectly influences consumer trust in an organization.

- Knowledge-based trust is positively affected by products and services as well as emotional appeal. According Podnar et al. (2012), the influence of consumer trust in an organisation on corporate reputation is particularly revealed through corporate reputation's emotional appeal dimension.

- Financial performance, products and services, social responsibility, and emotional appeal influence identification-based consumer trust. This finding is in line with previous studies on consumer trust and corporate reputation. Walsh and Beatty (2007) and Walsh et al. (2009) demonstrated that the quality of goods and services is the most important criterion for consumer trust in an organization. The following criteria are also often mentioned as financial stability of the organization, consumer orientation, and good status of the organization as an employer, social and environmental responsibility. This view is supported by Terblanche (2014), Walsh and Beatty (2007), Walsh et al. (2009, 2013).

In most cases the research findings are logical and indisputable. However, the lack of positive impact links between certain dimensions of corporate reputation and consumer trust in the analysed pharmacy network was noticed, which could not be easily explained. Calculusbased consumer trust is not built when some areas of company's activity related to corporate reputation (e.g., company's social responsibility) do not create value to consumer. Knowledge-based consumer trust is not observed when information about certain areas of company's activity (e.g., company's financial performance and social responsibility) are not priority to consumers.

It should be emphasized that the results of the empirical research do not negate the research findings in the scientific literature but contribute to the development of further research, highlighting the unexplored positive impact of specific dimensions of corporate reputation not only on consumers but also on other types of key stakeholders.

\section{Insight for Future Research}

Comparison of theoretical and empirical research findings leads to a conclusion that it would be relevant to perform a more in-depth theoretical and empirical analysis of the emotional appeal dimension of corporate reputation. In addition, to find the solution for the issue of decreasing consumer and other stakeholder trust on a wider scale, it would be worth to perform empirical research into other sectors that face this problem after the research methodology developed in this article.

Future research could examine consumers of other countries or conduct cross-national research to generalize 
these results. The research instrument used refined indicators to measure the dimensions of the corporate reputation and their statements, adapting them to research in the pharmaceutical sector. In the statistical analysis, the survey instrument was adjusted to obtain data close to the variables' normal distribution. The adjustments made standardize the instrument concerning the study population, so it cannot be applied to studies in another population. It should be noted that from a current pandemic's visible impact on consumer and other stakeholder confidence in the organization and changing expectations, it would be appropriate to repeat research on the importance and impact of reputation dimensions on trust.
In research conducted by researchers in marketing, management, and communication, the impact of corporate reputation on trust in the organization is usually analysed from only one stakeholder. It would be useful to study the impact of corporate reputation on the different trust type of its several vital stakeholders such as customers, employers, suppliers, and others.

\section{Acknowledgements}

The authors would like to thank two anonymous reviewers for their helpful comments in relation to the revision of the manuscript.

\section{References}

Abdul, W. K., Gaur, S. S., \& Penaloza, L. N. (2012). The determinants of customer trust in buyer-seller relationships: an empirical investigation in rural India. Australasian Marketing Journal, 20, 303-313. https://doi.org/10.1016/j.ausmj. 2012.07.004

Abratt, R., \& Kleyn, N. (2012). Corporate identity, corporate branding and corporate reputations. Reconciliation and integration. European Journal of Marketing, 46 (7/8), 1048-1063. https://doi.org/10.1108/03090561211230197

Alan, A. K., \& Kabadayi, E. T. (2014). Quality antecedents of brand trust and behavioral intention. Procedia - Social and Behavioral Sciences, 150, 619-627. https://doi.org/10.1016/j.sbspro.2014.09.081

Backhaus, K., \& Tikoo, S. (2004). Conceptualizing and researching employer branding. Career Development International, 9 (5), 501-517. https://doi.org/10.1108/13620430410550754

Barnett, M. L., Jermier, J. M., \& Lafferty, B. A. (2006). Corporate reputation: the definitional landscape. Corporate Reputation Review, 9 (1), 26-38. https://doi.org/10.1057/palgrave.crr.1550012

Bennett, R., \& Gabriel, H. (2001). Reputation, trust and supplier commitment: the case of shipping company/seaport relations. Journal of Business \& Industrial Marketing, 16 (6), 424-438. https://doi.org/10.1108/EUM0000000006018

Berthon, P., Ewing, M., \& Hah, L. L. (2005). Captivating company: dimensions of attractiveness in employer branding. International Journal of Advertising, 24(2), 151-172. https://doi.org/10.1080/02650487.2005.11072912

Cassia, F., Ugolini, M. M., Cobelli, N., \& Gill, L. (2015). Service-based vs. goods-based positioning of the product concept. Effects on customer perceived value. The TQM Journal, 27 (2), 247-255. https://doi.org/10.1108/TQM-01-2015-0005

Cekanavicius, V., \& Murauskas, G. (2014). Taikomoji regresine analize socialiniuose tyrimuose. Vilnius: Vilniaus universiteto leidykla.

Cravens, K., Oliver, E. G., \& Ramamoorti, S. (2003). The reputation index: measuring and managing corporate reputation. European Management Journal, 21 (2), 201-212. https://doi.org/10.1016/S0263-2373(03)00015-X

Cross, M. E., Brashear, T. G., Rigdon, E. E., \& Bellenger, D. N. (2007). Customer orientation and salesperson performance. European Journal of Marketing, 41 (7/8), 821-835. https://doi.org/10.1108/03090560710752410

Curras-Perez, R., \& Sanchez-Garcia, I. (2016). Antecedents and consequences of consumer commitment in traditional and low-cost airlines. Journal of Travel \& Tourism Marketing, 33, 899-911. https://doi.org/10.1080/10548 408.2015.1075458

Da Costa Hernandez, J. M., \& dos Santos, C. C. (2010). Development-based trust: proposing and validating a new trust measurement model for buyer-seller relationships. Brazilian Administration Review, 7(2), 172-197. https://doi.org/ $10.1590 / \mathrm{S} 1807-76922010000200005$

Dietz, G., \& Hartog, D. N. D. (2006). Measuring trust inside organisations. Personnel Review, 35(5), 557-588. https://doi.org/10.1108/00483480610682299

Eisingerich, A. B., \& Bell, S. J. (2008). Perceived service quality and customer trust. Does enhancing customers' service knowledge matter? Journal of Service Research, 10(3), 256-268. https://doi.org/10.1177/1094670507310769

Fatma, M., Rahman, Z., \& Khan, I. (2015). Building company reputation and brand equity through CSR: the mediating role of trust. International Journal of Bank Marketing, 33 (6), 840-856. https://doi.org/10.1108/IJBM-11-2014-0166

Fombrun, C. J., Gardberg, N. A., \& Sever, J. M. (2000). The Reputation Quotient: a multi - stakeholder measure of corporate reputation. The Journal of Brand Management, 7(4), 241-255. https://doi.org/10.1057/bm.2000.10

Fombrun, C. J., Ponzi, L. J., \& Newburry, W. (2015). Stakeholder tracking and analysis: the RepTrak system for measuring corporate reputation. Corporate Reputation Review, 18 (1), 3-24. https://doi.org/10.1057/crr.2014.21 
Fombrun, C., \& van Riel, C. (1997). The reputational landscape. Corporate Reputation Review, 1 (1/2), 5-13. https://doi.org/10.1057/palgrave.crr.1540008

Foster, C., Punjaisri, K., \& Cheng, R. (2010). Exploring the relationship between corporate, internal and employer branding. Journal of Product \& Brand Management, 19(6), 401-409. https://doi.org/10.1108/10610421011085712

Ganguli, S., \& Roy, S. K. (2013). Conceptualisation of service quality for hybrid services: a hierarchical approach. Total Quality Management, 24(10), 1202-1218. https://doi.org/10.1080/14783363.2013.814293

Garvin, D. E. (1984). What does "product quality" really mean? Sloan Management Review, Fall, $25-43$.

Guenzi, P., \& Georges, L. (2010). Interpersonal trust in commercial relationships. Antecedents and consequences of customer trust in the salesperson. European Journal of Marketing, 44(1/2), 114-138. https://doi.org/ $10.1108 / 03090561011008637$

Hillenbrand, C., \& Money, K. (2009). Segmenting stakeholders in terms of corporate responsibility: implications for reputation management. Australasian Marketing Journal, 17, 99-105. https://doi.org/10.1016/j.ausmj.2009.05.004

Hussain, R., Nasser, A. A., \& Hussain, Y. K. (2015). Service quality and customer satisfaction of a UAE-based airline: an empirical investigation. Journal of Air Transport Management, 42, 167-175. https://doi.org/10.1016/ j.jairtraman.2014.10.001

Iacob, A. (2014). Individual antecedents of employee's customer orientation in public services. In The 7th Edition of the International Conference "Marketing - from information to decision", 7-8 November 2014, Romania (pp. 137-148). Romania: Cluj-Napoca.

Idrissou, L., van Paassen, A., Aarts, N., Vodouhe, S., \& Leeuwis, C. (2013). Trust and hidden conflict in participatory natural resources management: the case of the Pendjari national park (PNP) in Benin. Forest Policy and Economics, 27, 65-74. https://doi.org/10.1016/j.forpol.2012.11.005

Jalilvand, M. R., Vosta, L. N., Mahyari, H. K., \& Pool, J. K. (2017). Social responsibility influence on customer trust in hotels: mediating effects of reputation and word-of mouth. Tourism Review, 72 (1), 1-14. https://doi.org/10.1108/TR09-2016-0037

Jimenez, N., \& San-Martin, S. (2016). The central role of the reputation of country-of-origin firms in developing markets. Journal of Business \& Industrial Marketing, 31 (3), 349-364. https://doi.org/10.1108/JBIM-02-2013-0045

Kang, J., \& Hustvedt, G. (2014). Building trust between consumers and corporations: the role of consumer perceptions of transparency and social responsibility. Journal of Business Ethics, 125, 253-265. https://doi.org/10.1007/s10551-0131916-7

Keh, H. T., \& Xie, Y. (2009). Corporate reputation and customer behavioral intentions: the roles of trust, identification and commitment. Industrial Marketing Management, 38, 732-742. https://doi.org/10.1016/j.indmarman.2008.02.005

Krejcie, R. V., \& Morgan, D. W. (1970). Determining sample size for research activities. Educational and psychological measurement, 30, 607-610. https://doi.org/10.1177/001316447003000308

Lacey, R., \& Kennett-Hensel, P. A. (2010). Longitudinal effects of corporate social responsibility on customer relationships. Journal of Business Ethics, 97, 581-597. https://doi.org/10.1007/s10551-010-0526-X

Laeequddin, M., Sahay, B. S., Sahay, V., \& Waheed, A. (2010). Measuring trust in supply chain partners' relationships. Measuring Business Exellence, 14(3), 53-69. https://doi.org/10.1108/13683041011074218

Lander, M. C., Purvis, L. R., McCray, G. E., \& Leigh, W. (2004). Trust-building mechanisms utilized in outsourced IS development projects: a case study. Information \& Management, 41, 509-528. https://doi.org/10.1016 /j.im.2003.10.001

Lau, R. S., \& Cobb, A. T. (2010). Understanding the connections between relationship conflict and performance: the intervening roles of trust and exchange. Journal of Organizational Behavior, 31, 898-917. https://doi.org/ 10.1002/job.674

Lien, C. H., Wu, J. J., Chen, Y. H., \& Wang, C. J. (2014). Trust transfer and the effect of service quality on trust in the healthcare industry. Managing Service Quality, 24 (4), 399-416. https://doi.org/10.1108/MSQ-11-2013-0255

Lin, C. P., Chen, S. C., Chiu, C. K., \& Lee, W. Y. (2011). Understanding purchase intention during product-harm crises: moderating effects of perceived corporate ability and corporate social responsibility. Journal of Business Ethics, 102, 455-471. https://doi.org/10.1007/s10551-011-0824-y

Maden, C., Arikan, A., Telci, E. E., \& Kantur, D. (2012). Linking corporate social responsibility to corporate reputation: a study on understanding behavioral consequences. Social and Behavioral Sciences, 58, 655-664. https://doi.org/10.1016/j.sbspro.2012.09.1043

Manning, L. (2013). Corporate and consumer social responsibility in the food supply chain. British Food Journal, 115 (1), 9-29. https://doi.org/10.1108/00070701311289858 
Olmedo-Cifuentes, I., Martinez-Leon, I. M., \& Davies, G. (2014). Managing internal stakeholders' views of corporate reputation. Service Business, 8, 83-111. https://doi.org/10.1007/s11628-013-0188-8

Omar, M., Williams Jr, R. L., \& Lingelbach, D. (2009). Global brand market-entry strategy to manage corporate reputation. Journal of Product \& Brand Management, 18 (3), 177-187. https://doi.org/10.1108/10610420910957807

Page, G., \& Fearn, H. (2005). Corporate reputation: what do consumers really care about? Journal of Advertising Research, 45 (3), 305-313. https://doi.org/10.1017/S0021849905050361

Park, J., Gunn, F., \& Han, S. L. (2012a). Multidimensional trust building in e-retailing: cross-cultural differences in trust formation and implications for perceived risk. Journal of Retailing and Consumer Services, 19, 304-312. https://doi.org/10.1016/j.jretconser.2012.03.003

Park, J., Lee, H., \& Kim, C. (2014). Corporate social responsibilities, consumer trust and corporate reputation: South Korean consumers' perspectives. Journal of Business Research, 67, 295-302. https://doi.org/10.1016/j.jbusres.2013.05.016

Park, J., Lee, J., Lee, H., \& Truex, D. (2012b). Exploring the impact of communication effectiveness on service quality, trust and relationship commitment in IT services. International Journal of Information Management, 32, 459-468. https://doi.org/10.1016/j.ijinfomgt.2012.02.005

Peloza, J., Loock, M., Cerruti, J., \& Muyot, M. (2012). Sustainability: how stakeholder perceptions differ from corporate reality. California Management Review, 55 (1), 74-97. https://doi.org/10.1525/cmr.2012.55.1.74

Perrini, F., Castaldo, S., Misani, N., \& Tencati, A. (2010). The impact of corporate social responsibility associations on trust in organic products marketed by mainstream retailers: a study of Italian consumers. Business Strategy and the Environment, 19, 512-526. https://doi.org/10.1002/bse.660

Pivato, S., Misani, N., \& Tencati, A. (2008). The impact of corporate social responsibility on consumer trust: the case of organic food. Business Ethics: A European Review, 17 (1), 3-12. https://doi.org/10.1111/j.1467-8608.2008.00515.x

Podnar, K., Tuskej, U., \& Golob, U. (2012). Mapping semantic meaning of corporate reputation in global economic crisis context: a Slovenian study. Public Relations Review, 38, 906-915. https://doi.org/10.1016/j.pubrev.2012.08.003

Ruiz, B., Esteban, A., \& Gutierrez, S. (2014). Determinants of reputation of leading Spanish financial institutions among their customers in a context of economic crisis. Business Research Quarterly, 17, 259-278. https://doi.org/10.1016/j.brq.2014.04.002

Sah, N. F. M., \& Abdullah, Z. (2016). The customers' perception toward secret recipe's reputation by using the Reptrak model. In Pyeman J., Wan Rashid W., Hanif A., Syed Mohamad S., Tan P. (Eds.), Proceedings of the 1st AAGBS International Conference on Business Management 2014 (AiCoBM 2014) (pp. 29-40). Singapore: Springer. https://doi.org/10.1007/978-981-287-426-9_3

Schanz, K. U. (2009). Maintaining stakeholder trust in difficult times: some fundamental reflections in light of the credit crisis. The Geneva Papers, 34, 260-270. https://doi.org/10.1057/gpp.2009.4

Schwaiger, M. (2004). Components and parameters of corporate reputation - an empirical study. Schmalenbach Business Review, 56, 46-71. https://doi.org/10.1007/BF03396685

Sebastianelli, R., \& Tamimi, N. (2002). How product quality dimensions relate to defining quality. International Journal of Quality \& Reliability Management, 19 (4), 442-453. https://doi.org/10.1108/02656710210421599

Semuel, H., \& Chandra, S. S. (2014). The analysis of corporate social responsibility implementation effects towards price fairness, trust and purchase intention at oriflame cosmetics product in Surabaya. Procedia - Social and Behavioral Sciences, 155, 42-47. https://doi.org/10.1016/j.sbspro.2014.10.253

Shahsavari, A., \& Faryabi, M. (2013). The effect of customer-based corporate reputation on customers' citizenship behaviors in banking industry. Research Journal of Applied Sciences, Engineering and Technology, 6 (20), 37463755. https://doi.org/10.19026/rjaset.6.3586

Shamma, H. M., \& Hassan, S. S. (2009). Customer and non-customer perspectives for examining corporate reputation. Journal of Product \& Brand Management, 18 (5), 326-337. https://doi.org/10.1108/10610420910981800

Siano, A., Kitchen, P. J., \& Confetto, M. G. (2010). Financial resources and corporate reputation. Toward common management principles for managing corporate reputation. Corporate Communications: An International Journal, 15 (1), 68-82. https://doi.org/10.1108/13563281011016840

Singh, R., \& Koshy, A. (2012). A new conceptualization of salesperson's customer orientation. Propositions and implications. Marketing Intelligence \& Planning, 30(1), 69-82. https://doi.org/10.1108/02634501211193921

Stanaland, A. J. S., Lwin, M. O., \& Murphy, P. E. (2011). Consumer perceptions of the antecedents and consequences of corporate social responsibility. Journal of Business Ethics, 102, 47-55. https://doi.org/10.1007/s10551-011-0904-z

Stoecklin-Serino, C. M. (2009). Building trust: an examination of the impacts of brand equity, security, and personalization on trust processes. Journal of Organizational and End User Computing, 21 (1), 1-36. https://doi.org/10.40 18/joeuc.2009010101 
Terblanche, N. S. (2014). Validation of the customer-based corporate reputation scale in a retail context. International Journal of Market Research, 56(5), 655-671. https://doi.org/10.2501/IJMR-2014-044

Tian, Z., Wang, R., \& Yang, W. (2011). Consumer responses to corporate social responsibility (CSR) in China. Journal of Business Ethics, 101, 197-212. https://doi.org/10.1007/s10551-010-0716-6

Tong, S. C. (2015). Financial communication in initial public offerings Risk estimate in the interplay of organizational trust, organizational reputation and media influences. Corporate Communications: An International Journal, 20 (1), 30-47. https://doi.org/10.1108/CCIJ-02-2014-0006

Verhoeven, J. W. M., van Hoof, J. J., Keurs, V. T., \& van Vuuren, M. (2012). Effects of apologies and crisis responsibility on corporate and spokesperson reputation. Public Relations Review, 38, 501-504. https://doi.org/10.10 16/j.pubrev.2012.02.002

Walsh, G., \& Beatty, S. E. (2007). Customer-based corporate reputation of a service firm: scale development and validation. Journal of the Academy of Marketing Science, 35, 127-143. https://doi.org/10.1007/s11747-007-0015-7

Walsh, G., Beatty, S. E., \& Shiu, E. M. K. (2009). The customer-based corporate reputation scale: replication and short form. Journal of Business Research, 62, 924-930. https://doi.org/10.1016/j.jbusres.2007.11.018

Walsh, G., Shiu, E., \& Hassan, L. M. (2013). Replicating, validating, and reducing the length of the consumer perceived value scale. Journal of Business Research, 67, 260-267. https://doi.org/10.1016/j.jbusres.2013.05.012

Wilden, R., Gudergan, S., \& Lings, I. (2010). Employer branding: strategic implications for staff recruitment. Journal of Marketing Management, 26 (1/2), 56-73. https://doi.org/10.1080/02672570903577091

Zehir, C., Sahin, A., Kitapci, H., \& Ozsahin, M. (2011). The effects of brand communication and service quality in building brand loyalty through brand trust; The empirical research on global brands. Procedia Social and Behavioral Sciences, 24, 1218-1231. https://doi.org/10.1016/j.sbspro.2011.09.142

Zhou, T., Lu, Y., \& Wang, B. (2009). The relative importance of website design quality and service quality in determining consumers' online repurchase behavior. Information Systems Management, 26, 327-337. https://doi.org/10.10 $80 / 10580530903245663$

\section{Authors' biographies}

Jurgita Stravinskienè received her $\mathrm{PhD}$ in Management and Administration (Social Science) from Kaunas University of Technology in 2000. Since 1996 till 2017 she worked at the Department of Marketing, Kaunas University of Technology. Currently she is a member of the Sustainable Management Science Group. Her areas of research interest include public relations, communication management, and reputation management.

Migle Matulevičienė is a $\mathrm{PhD}$ in Management (Social Sciences). She received her $\mathrm{PhD}$ in Management (Social Sciences) from Kaunas University of Technology in 2018. Her areas of research interest include public relations, communication management, and reputation management.

Rimantė Hopenienė is an Associate Professor in Kaunas University of Technology, School of Economics and Business. She received her PhD in Management and Administration (Social Science) from Kaunas University of Technology in 2009. Currently she is a member of the Sustainable Management Science Group. Her research interests: entrepreneurship marketing, business-to-business relationship marketing and management, service marketing, place marketing and tourism management.

The article has been reviewed. Received in August 2020; accepted in April 2021.

This article is an Open Access article distributed under the terms and conditions of the Creative Commons Attribution 4.0 (CC BY 4.0) License (http://creativecommons.org/licenses/by/4.0/). 